\title{
ROZWÓJ PRAWA JAPOŃSKIEGO \\ OD POCZĄTKÓW PAŃSTWOWOŚCI JAPONII DO ROZPOCZECIA OKRESU EDO W 1603 R. ZARYS ZAGADNIEŃ
}

Pržestudiuj przeszłość, jeśli chcesz zdefiniować prayszzłość.

Konfucjusz

\section{Wprowadzenie}

Japonia stanowi interesujący przypadek demokratycznego państwa, które łączy silną tradycję i tożsamość narodową z jedną z najważniejszych i najnowocześniejszych w skali światowej potęg przemysłowych ${ }^{1}$. W polskiej doktrynie prawniczej zagadnienia dotyczące japońskiego systemu prawnego i kształtujących go specyficznych uwarunkowań historycznych sprzed XVII w. nie stanowiły do tej pory przedmiotu szerszych badań. Dzieje Japonii cechują się blisko całkowitym brakiem wpływów cywilizacji zachodniej.

W niniejszym artykule postawiłem trzy cele. Po pierwsze, przedstawienie pogłębionych badań nad kształtem i rozwojem japońskiego systemu prawnego, począwszy od genezy państwowości do 1603 r., uznawanego powszechnie za datę rozpoczęcia okresu Edo (江戸時代) ${ }^{2}$. Po drugie, przybliżenie wiedzy na temat istniejących w Japonii specyficznych uwarunkowań, co pozwoli lepiej zrozumieć współczesny porządek prawny tego państwa i zachodzące w nim korelacje norm społecznych. Po trzecie, artykuł ma rozbudzić większe zainteresowanie azjatyckimi systemami prawnymi i zaprosić do kontynuowania badań w tym kierunku.

ORCID: 0000-0001-8887-2249, DOI: 10.4467/23538724GS.21.009.14841

1 Zob. Gross domestic product (current US\$), World Bank national accounts data, and OCED National Accounts data files, The World Bank, https://data.worldbank.org/indicator/NY.GDP.MKTP.CD (dostęp: 12.02.2021).

2 Zwany również okresem Tokugawa (德川時代). Jego początek uważa się powszechnie za koniec średniowiecza w Japonii. 
Przed wprowadzeniem polityki restrykcyjnego izolacjonizmu ${ }^{3}$ (tzw. sakoku, 鎖国 lub tzw. kaikin, 海禁) ${ }^{4}$ w okresie Edo i następczego otwarcia na świat zewnętrzny Japonia podlegała znacznym wpływom chińskim. W artykule stawiam tezę, że pomimo roli przewodniej, jaką odegrało Państwo Środka w regionie azjatyckim, Japonia do zakończenia okresu średniowiecza wykorzystywała zaczerpywane wzorce kulturowe w sposób selektywny, dostosowany do odmiennych warunków, a zarazem pozwalający na ich zharmonizowanie z rodzimą kulturą. Dlatego zaznajamiając się z obecnym japońskim systemem prawnym, nie sposób pominąc znaczenia opisywanych okresów historycznych, w tym zachodzących w nich procesów. Co więcej, państwo japońskie wyróżnia się wielością różnorodnych i oddziałujących na siebie norm, które istotnie wpływają na tożsamość narodowa i życie codziennie Japończyków, jak również na sposób kształtowania porząaku prawnego. W związku z tym $\mathrm{w}$ artykule omawiam najważniejsze kwestie prawno-systemowe i społeczne we wskazanym okresie, a dominującą metodą badawczą jest metoda historycznoprawna.

\section{Geneza państwa japońskiego}

Archipelag japoński został zdobyty przez człowieka ok. 30 tys. lat p.n.e. w okresie paleolitu ${ }^{5}$ na skutek migracji oraz kształtowania mas lądowych w ramach powolnego procesu dryfu kontynentów. Procesy te spowodowały odpowiednie położenie Wysp Japońskich i Azji kontynentalnej, które dzięki istnieniu swoistych naturalnych mostów i obniżeniu poziomu wody nie stanowiły bariery geograficznej dla ekspansji ludności ${ }^{6}$. Geneza państwa japońskiego sięga okresu Jōmon (縄文時代), którego rozpoczęcie datuje się na ok. 13 tys. lat p.n.e., kiedy to zaczęto wytwarzać najstarsze, odnalezione podczas badań archeologicznych, naczynia ceramiczne. Uznaje się, że od ok. 5 tys. lat p.n.e. tryb życia homo sapiens zaczął ulegać zmianie z wędrowniczego do pożądanego trybu osiadłego. Formowały się większe grupy społeczności plemiennych, które różniły się od siebie zarówno pod względem zamieszkiwanych regionów, jak i stosowanej technologii. Wynikało to bowiem $z$ występowania odmiennych warunków otoczenia i zachodzących zmian klimatycznych ${ }^{7}$. Trwającego

\footnotetext{
3 Okres samoizolacji Japonii trwał od 1639 do 1853 r.

4 Zawarte w artykule wyrazy obce pochodzą z języka japońskiego, chyba że wskazano inny język.

5 A. Ono, Modern homonids in the Japanese Islands and the early use of obsydian: the case of Onbase Islet [w:] Human Origin Sites and the World Heritage Convention in Asia. World Heritage HEADS 3, papers 39, ed. N. Sanz, Paris - Mexico 2014, s. 157 i nn.

6 K. Henshall, A History of Japan, $3^{\text {rd }}$ ed., London 2012, s. 7 i nn.

7 Ibidem. Kwestia migracji nowej ludności we wspomnianym okresie pozostaje otwarta dla badaczy. Przy czym uznaje się, że nie była liczna lub nie różniła się wyglądem od ludności Jōmon.
} 
kilka tysięcy lat okresu Jōmon nie można więc postrzegać w sposób jednolity. Ówczesna ludność cechowała się pewnym stopniem etnicznej różnorodności. W tym czasie w zbiorowościach plemiennych pojawił się szamanizm, animizm i rytualizm, które opierały się na wierze w zjawiska nadprzyrodzone, a w późniejszym okresie przerodziły się w tradycyjna, rodzimą dla Japończyków religię shintō (神道; 神なが らの道), bazującą na macierzystej mitologii i politeizmie ${ }^{8}$.

Tradycyjnie przyjmuje się, że Jōmon zakończył się ok. 400-300 r. p.n.e. ${ }^{9}$ Po nim zaś nastapił okres Yayoi (弥生時代) ${ }^{10}$, charakteryzujący się nasiloną migracją ludności w kierunku Wysp Japońskich. Proces ten spowodował intensywny wpływ kultury chińskiej i wprowadzenie do obrotu ulepszonych technik metalurgicznych, nowego garncarstwa, rozpoczęcia używania brązu i żelaza, które pozwoliły na rozwinięcie istniejących już narzędzi rolniczych i broni ${ }^{11}$. Powstało rolnictwo, a wraz z nim pojawiła się kultywacja mokrych pól ryżowych na niespotykaną dotąd na ziemiach japońskich skalę ${ }^{12}$. Rozpowszechnienie surowców naturalnych (zwłaszcza

8 N. Hirai, Shintō [w:] Encyclopedia Britannica, www.britannica.com/topic/Shinto (dostęp: 12.02.2021). Nazwa tej religii tłumaczona jest jako „droga bogów”. Shintoizm nie cechuje się centralizacją swojej organizacji i wierzeń, dlatego też wykazuje pewne podobieństwo do przedchrześcijańskiego poganizmu istniejącego w Europie. Stanowi zbiór wielu różnorodnych kultów związanych chociażby z wszechotaczającą człowieka natura, animizmem i elementami szamanizmu. Japończycy kultywują shintoizm również współcześnie, wywodząc z niego tradycyjne praktyki religijne, zwyczaje i wierzenia. Wynika z nich powinność poszukiwania harmonii i równowagi w świecie pomiędzy natura, człowiekiem i bóstwami kami (神), którym należy się podziw i wdzięczność. Shintō można łatwiej zaobserwować w indywidualnej motywacji jednostki niż w formalnych wzorach wierzeń czy filozofii. Dzięki temu odznacza się elastycznym charakterem, umożliwiającym ścisłe współistnienie i związanie z japońskim systemem wartości oraz sposobem myślenia i podejmowania działań.

${ }^{9} \mathrm{~K}$. Henshall, $A$ History of Japan... Jednak współczesne badania oparte na technologii DNA wskazują na rozpoczęcie okresu Yayoi ok. 1000 r. p.n.e., a nawet ok. 3200 r. p.n.e.; zob. T.A. Jinam, H. Kanzawa-Kiriyama, N. Saitou, Human genetic diversity in the Japanese Archipelago: dual structure and beyond, „Genes \& Genetics Systems” 2015, vol. 90, issue 3, s. 149 i nn.; por. The Yayoi Period (400 B.C. to 300 A.D.), 27.04.2020, www.japan-experience.com/to-know/the-history-of-japan/ yayoi-period (dostęp: 12.02.2021).

${ }^{10} \mathrm{~K}$. Henshall, A History of Japan...

11 Zob. M. Cartwright, Ancient Japanese \& Chinese Relations, Ancient History Encyclopedia, 27.06.2017, www.ancient.eu/article/1085/ancient-japanese--chinese-relations/ (dostęp: 12.02.2021).

$12 \mathrm{~K}$. Henshall, A History of Japan... Wbrew niekiedy intuicyjnemu myśleniu i powszechnemu przeświadczeniu o pochodzeniu ryżu (opartym na wizji tradycyjnej Japonii), został on sprowadzony na tereny Wysp Japońskich dopiero ok. 3 tys. lat p.n.e. z obszaru współczesnych Chin lub Półwyspu Koreańskiego. Fakt ten plasuje Japonię na ostatnim miejscu pod względem przeszczepienia uprawy ryżu na tle innych krajów azjatyckich; por. B.L. Grossa, Z. Zhao, Archaeological and genetic insights into the origins of domesticated rice, „Proceedings of the National Academy of Sciences of the United States of America" 2014, vol. 111, no. 17, s. $6190 \mathrm{i} \mathrm{nn.} \mathrm{Na} \mathrm{podstawie} \mathrm{nowych} \mathrm{ba-}$ dań dominuje pogląd, że kolebką udomowienia ryżu przez człowieka (ok. 8050 r. p.n.e.), a także 
w południowo-zachodniej części współczesnej Japonii) obrazuje położenie fundamentów pod genezę kultury japońskiej oraz prawdopodobny kierunek przemieszczania i osiedlania się nowych przybyszy. Zjawisko migracji doprowadziło do zmieszania się dwóch odmiennych grup: rozproszonej ludności Jōmon (縄文人), zamieszkującej już ówcześnie archipelag japoński, oraz odmiennej kulturowo i genetycznie ludności Yayoi (弥生人), której dokładne pochodzenie geograficzne jest sporne, chociaż uważa się, że emigrowała z terenów Azji kontynentalnej przez Półwysep Koreański na wyspę Kiusiu (九州) lub Sikoku (四国). Napływająca ludność Yayoi wywarła duży wpływ na współczesną japońską tożsamość narodową, w szczególności ze względu na zmieszanie się z zamieszkującą już archipelag ludnością ${ }^{13}$. Obecny szeroko akceptowany i wsparty badaniami genetycznymi model pochodzenia Japończyków (z wyłączeniem mieszkańców Okinawy) cechuje się podwójną struktura, co odzwierciedla efekt zmieszania krwi dwóch wyżej omówionych grup ${ }^{14}$.

Kenneth Henshall wskazuje, że z uwagi na ograniczone złoża metali na terenie Japonii surowce te stały się symbolem wyższego statusu społecznego, a wraz z rozwojem agrokultury spowodowały powstanie zjawiska stratyfikacji społecznej. Ludność archipelagu w sposób bardziej trwały związała się z miejscem swojego osiedlenia, co prowadziło do większej identyfikacji z zamieszkiwanymi terenami oraz umożliwiało elitom społecznym sprawowanie efektywniejszej kontroli. Pod wpływem tych czynników, a także wzrostu populacji dochodziło do zwiększonej rywalizacji, aktów niewolnictwa oraz walk o dominację pomiędzy rozproszonymi plemionami. Różnorodność terytorialna doprowadziła do wykształcenia odmiennych rzemiosł i wzrostu znaczenia handlu, w tym również z państwami ościennymi. Przywódcy poszczególnych plemion zaczęli zawierać ze sobą sojusze, które w następstwie prowadziły do formowania się licznych małych królestw ${ }^{15}$.

jego późniejszej kultywacji i rozprzestrzenienia, jest kilka obszarów występujących przy rzece Jangcy we współczesnych Chinach.

13 T.A. Jinam, H. Kanzawa-Kiriyama, N. Saitou, Human genetic...

14 Ibidem. Współczesne badania wskazują, że obecni Japończycy odziedziczyli jedynie od kilku do kilkunastu procent genów ludności Jōmon. Z kolei geny ludności Yayoi dominują, co dowodzi genetycznego pokrewieństwa z Chińczykami i Koreańczykami; por. Y. Furuichi, 'Jomon woman' helps solve Japan's genetic mystery, NHK World - Japan, 11.06.2019, www3.nhk.or.jp/nhkworld/en/ news/backstories/555/ (dostęp: 12.02.2021); M. Fackler, Japanese roots surprisingly shallow. Migrants from mainland planted new culture around 400 B.C., „The Japan Times”, 31.08.1999.

$15 \mathrm{~K}$. Henshall, A History of Japan..., s. 13 i nn. 


\section{Okres Yamato (大和時代) $)^{16}$}

Kultura japońska przenikała się z koreańską, a kiedy Chiny ok. I w. p.n.e. założyły kolonie w północnej części Półwyspu Koreańskiego, zaczęła tu napływać i rozprzestrzeniać się kultura chińska ${ }^{17}$. Od tego czasu, jak wskazują kroniki historyczne, pojawiły się pierwsze wzmianki o wciąż podzielonym państwie japońskim, nazywanym Wa, Wō lub Wae (倭; chiń. 倭; kor. 왜) ${ }^{18}$. Z początku w jego skład wchodziło około stu klanów, zaś część z nich została zobligowana do składania regularnych danin dla Chin. Wraz z nadejściem i rozwojem okresu Yamato, który rozpoczą się ok. 250-300 r. n.e., doszło do zjednoczenia narodu japońskiego. Klan Yamato (和氏; 和史) utworzył federację plemienna, która zaczęła inkorporować pozostałe rody i zyskiwać nad nimi kontrolę ${ }^{19}$. W ten sposób w IV w. n.e. powstała ponadlokalna japońska struktura państwowa ${ }^{20}$. Na tym etapie państwowości prawo japońskie nie wyróżniało się znacznie na tle innych norm społecznych, w szczególności norm religijnych ${ }^{21}$. Równocześnie z masowym przybywaniem rzemieślników od początku okresu Yamato do Japonii wędrowali wykształceni mnisi. Religie, najpierw konfucjanizm (od 285 r.), a w późniejszym czasie buddyzm (od 538 r.), rozprzestrzeniły się w państwie i jako jeden z przyszłych filarów społeczeństwa zaczęły wpływać na kształt polityki, etyki oraz obyczajów ${ }^{22}$. W ciąu kolejnych wieków prawdopodobnie niepiśmienne społeczeństwo japońskie zaadaptowało pismo chińskie i wykształciło scentralizowany ośrodek władzy w postaci dworu cesarskiego. Opanowano tereny południowo-zachodnich wysp Archipelagu Japońskiego, w tym m.in. znaczną część wyspy Honsiu (本州), wyspę Sikoku (四国) oraz północną część wyspy Kiusiu (九州) ${ }^{23}$.

16 Nazwa okresu historycznego nawiązuje do miejsca zamieszkiwania rządzącego klanu Yamato, w którym później utworzono prefekturę o tej samej. Była ona usytuowana w obecnej prefekturze Nara (奈良県).

17 M. Cartwright, Ancient Japanese...

18 Chiński znak 倭, oznaczający „uległość”, „oddalenie”, „karłowatość”, został po kilkuset latach zastapiony homonimicznym znakiem 和, oznaczającym „harmonię”, „pokój”, „balans”; zob. M.H. Miyake, Old Japanese: A Phonetic Reconstruction, ed. 2, Tokyo 2013, s. 5 i nn.; Etymology of 'Wa', 'Yamatai' and Nippon', Heritage of Japan, www.heritageofjapan.wordpress.com/yayoiera-yields-up-rice/the-advent-of-agriculture-and-the-rice-revolution/who-was-queen-himiko/ etymology-of-wa-yamatai-and-nippon/ (dostęp: 12.02.2021).

19 C. Aikens, T. Higuchi, Prehistory of Japan, New York - London 1982, s. 335 i nn.

20 G.C. Hurst, Japan [w:] Encyclopaedia Britannica, www.britannica.com/place/Japan/History (dostęp: 12.02.2021).

21 Y. Noda, Introduction to Japanese Law, transl. and ed. A.H. Angelo, Tokyo 1976, s. 20 i nn.

22 N. Levi, The Impact of Confucianism in South Korea and Japan, „Acta Asiatica Varsoviensia” 2013, nr 26, s. 10 i nn.

23 Ibidem. 
W tym okresie zapoczątkowano japońską linię cesarską, która przetrwała do czasów współczesnych. U podstaw długowiecznej historii władców znajduje się rodzima mitologia, głosząca, że pierwszym cesarzem i protoplasta Japonii był Jimmu (神武天皇), który miał boskie pochodzenie i z pomocą bogini Amaterasu Ōmikami (天照; 天照大神; 天照大御神) wypełnił swój cel podbicia Archipelagu Japońskiego, w rezultacie czego założył państwo w 660 r. Cesarz japoński był zatem tytułowany „niebiańskim władcą” (tennō, 天皇) i sprawował władzę nad pozostałymi wodzami zespolonych w jedno państwo klanów ${ }^{24}$. Japonię zaczęto nazywać Nippon (日本), a następnie także Nihon (日本) 25 .

W tych początkowych dziejach Japonii można wyraźnie zaobserwować obce wpływy w kształtowaniu się kultury japońskiej, w tym wielopłaszczyznowe przejmowanie chińskich wzorców ${ }^{26}$. Jednakże w odróżnieniu od Półwyspu Koreańskiego Japonia efektywniej kontrolowała intensywne przenikanie obcych wartości kulturowych. Niezaprzeczalna i dominująca w całym regionie pozycja Państwa Środka zapewniała głównie jednostronną dyfuzję kulturową z sąsiadującymi krajami ${ }^{27}$. Japonia starała się utrzymywać polityczną niezależność względem Chin, dokonywała więc zapożyczeń kulturowych w sposób selektywny. Dzięki temu możliwe stało się weryfikowanie i świadome transponowanie większości zewnętrznych wzorców kulturowych (wraz z ewentualnymi ich modyfikacjami ${ }^{28}$ ) w zgodzie z japońskimi

24 Zob. B.-A. Shillony, 'Restoration', 'Emperor', 'Diet', 'Prefecture' or: How Japanese concepts were Mistranslated into Western Languages [w:] Rethinking Japan: Social sciences, ideology \& thought, eds. A. Boscaro, F. Gatti, M. Raveri, $2^{\text {nd }}$ ed., New York 2015, s. 300 i nn. Wraz z początkiem VII w. n.e. cesarz zaczął być tytułowany mianem „Syna Niebios” (天子; 天子樣), co stanowi bezpośrednie zapożyczenie językowe z dworu cesarskiego Chin.

25 Oba terminy funkcjonują oficjalnie do dziś i oznaczają dosłownie „pochodzenie słońca”, co tłumaczone jest jako „Kraj Wschodzącego Słońca”. Terminy te pochodzą bezpośrednio z japońskiej korespondencji cesarskiej z chińską dynastią Sui (chiń. 隋朝; lata 581-618) i odnoszą się do położenia Japonii na wschodzie względem położenia Chin.

26 D. Lu, Japan: A Documentary History: The Late Tokugawa Period to the Present, London 1996, s. $21 \mathrm{i} \mathrm{nn.}$

27 P.N. Stearns, The Spread of Chinese Civilization: Japan, Korea, and Vietnam [w:] World Civilizations, eds. P.N. Stearns, M.B. Adas, S.B. Schwartz, M.J. Gilbert, $7^{\text {th }}$ ed., London 2014, s. 394 i nn.

${ }^{28}$ K. Henshall, A History of Japan..., s. 25. Jako przykłady modyfikacji przejętych wzorców można wskazać system rang i pozycji społecznych w Japonii, który w odróżnieniu od chińskiego modelu był wówczas oparty bardziej na dziedziczonym statusie rodzinnym niż na merytorycznej wiedzy jednostki. Kenneth Henshall słusznie zauważa, że jak na ironię losu rozwiązanie to kontrastuje z tym, jak wielką wagę mają współcześnie egzaminy w japońskim społeczeństwie, jednak jest ono zrozumiałe z perspektywy ówczesnych elit, które pragnęły zachować władzę. Drugim przykładem jest tzw. mandat niebios (chiń. 天命), koncepcja wywodząca się z tradycyjnej chińskiej filozofii, głosząca, że władać może tylko cesarz sprawiedliwy, postępujący zgodnie z przyjętymi normami i dbający o społeczeństwo. Instytucja stanowiła swoisty wzorzec kontrolny będący zabezpieczeniem przed despotycznymi rządami cesarskimi. W warunkach japońskich 
wartościami ${ }^{29}$. W związku z tym można wysnuć wniosek, że pomimo silnych oddziaływań zewnętrznych, istniejących już we wczesnym etapie państwowości, Japonia zdołała skutecznie ochronić i rozwijać własną tożsamość narodową i kulturę.

Ewoluujące prawo japońskie ujednolicono na podstawie chińskiego porządku prawnego i etyki konfucjańskiej. Książę Shōtoku (聖德太子), działając z przyzwolenia cesarzowej Suiko (推古天皇), wprowadził w 604 r. tzw. Konstytucję siedemnastu artykułów (十七条憲法) ${ }^{30}$, zawierającą opisy wartości moralnych i etycznych, jakie powinny być przestrzegane $\mathrm{w}$ społeczeństwie japońskim ${ }^{31}$. Jednak regulacja ta nie odnosiła się wprost do systemu prawnego. Powyższy dokument nigdy nie został formalnie zniesiony i stanowi ważne historyczne źródło inspiracji. Rządzący Japonią władcy podejmowali wiele prób umocnienia państwa, również za pomocą powiększania mienia publicznego. Wprowadzano m.in. reformy zmierzające do konfiskat i rekwizycji majątków prywatnych (w szczególności gruntów). Dążenie do rozwoju państwa, zwiększenia liczebności wojsk, poprawy bezpieczeństwa i zapewnienia stabilności politycznej zaczęły wyraźnie wpływać na kształtowanie norm prawnych. Czynniki te doprowadziły do rozpoczęcia w VII w. pierwszego w Japonii długoletniego procesu kodyfikacji tworzonego systemu ritsuryō (律令). Odwzorowano go na wartościach konfucjańskich, pożądanym w społeczeństwie zachowaniu moralnym jednostki i chińskiej legislacji dynastii Tang (chiń. 唐朝). Ze względu na to, że ówcześnie nie istniało jeszcze pismo japońskie, jako oficjalnego używano chińskiego systemu zapisu, z którym to były zaznajomione głównie elity i wyższe klasy społeczne.

Trafnie zauważył Leszek Leszczyński, że filozofia konfucjańska odnalazła w Japonii bardzo dogodne warunki, które sprzyjały postępującemu zakorzenieniu kulturowemu, wynikającemu z pokrewieństwa cech dorobku społeczeństw oraz wartości związanych z tradycją japońską. Z jednej bowiem strony, inaczej niż w Chinach, społeczeństwo japońskie nie polemizowało na szerszą skalę z wartościami oferowanymi przez konfucjanizm. Z drugiej zaś strony, w dziejach Japonii aż do rozpoczęcia epoki Edo nie wystąpiły wydarzenia, które mogłyby zburzyć rozwijający się ład

cesarz był co do zasady nieusuwalny, gdyż celowo nie zawarto tego typu regulacji w japońskim odpowiedniku. Klan Yamato zajmował silna pozycję, a osądy społeczne nie mogły mieć wpływu na „boską” legitymację do sprawowania rządów. Inaczej niż w Chinach, rola kobiet w japońskiej domenie publicznej była ograniczana.

29 Ibidem.

30 十七条憲法と太子の思 [jū nana jō kenpō to taishi no shi], https://eifukuji-taishi.jp/17jyo. php (dostęp: 12.02.2021).

31 R. Tokarczyk, Wspótczesne kultury prawne, wyd. 9, Warszawa 2012, s. 272. Roman Tokarczyk przetłumaczył nazwę wskazanego aktu prawnego jako „Siedemnaście Maksym”. To ujęcie z jednej strony odbiega od oryginalnej nazwy i znaczenia wprowadzonej regulacji, z drugiej strony kładzie nacisk na treść i charakter norm z niej wynikających. 
zharmonizowanych ze sobą idei ${ }^{32}$. Tym samym recepcja wartości konfucjańskich była odbierana jako zjawisko pozytywne, powszechnie akceptowane i niekolidujące $z$ dojrzewająca na przestrzeni wieków kultura japońską ${ }^{33}$.

Proces kodyfikacji ritsuryō uczynił Japonię scentralizowanym państwem opartym na wspólnym prawie i umocnił władzę cesarska. Osiagnięcie to stanowiło poważne wyzwanie z uwagi na opór i rozległe wpływy klanów ${ }^{34}$, co jednak nie znaczyło, że japoński porządek prawny był jednolity. Składał się bowiem nie tylko z aktów prawa stanowionego pochodzących $z$ dworu cesarskiego, lecz także z wielu lokalnych norm prawnych, w tym praw zwyczajowych. W takim układzie niejednokrotnie mogło dochodzić do konfliktów. Istotny jest tu cały kontekst historyczny, a więc nasilająca się niekiedy rywalizacja o dominację pomiędzy poszczególnymi rodami, a także polityczne starcia o przychylność lub kontrolę dworu cesarskiego. Należy więc odróżnić dzierżenie realnej władzy od władzy niepełnej, związanej z brakiem rzeczywistej możliwości jej wyegzekwowania. Ponadto kolizje pomiędzy normami prawnymi a innymi normami społecznymi (np. zwyczajami) nie dawały bezwzględnego priorytetu tym pierwszym, gdyż a casu ad casum znaczenie miał charakter stojacych w opozycji norm oraz ich uznawanie i postrzeganie przez mieszkańców Japonii na danym terytorium. Głównymi celami reorganizowanego państwa japońskiego stało się ustabilizowanie pozycji cesarza, wprowadzenie silnej nacjonalizacji gruntów, redystrybucji ziemi, a także podziału administracyjnego, stałych podatków oraz służby wojskowej.

Do istotniejszych ówczesnych aktów prawnych wprowadzających zmiany systemowe należały Edykt o reformie Wielkiej Zmiany oraz Kodeks Taihō.

Edykt o reformie Wielkiej Zmiany (Taika no kaishin no mikotonori; 大化の改新の詔) wydany w czerwcu 645 r., który rozpoczął reformę Taika, mającą na celu koherentną regulację zbioru aktów prawnych cesarza Kōtoku (孝德天皇) i stanowiącą część kodyfikacji systemu ritsuryō. Edykt normował m.in. reorganizację rządu, zapowiedź zniesienia rodowej własności ziem i obalenia systemu danin względem rodów na

32 L. Leszczyński, O japońskim porz̨adku prawnym - między litera prawa a otwartościa norm, „Annales Universitatis Mariae Curie-Skłodowska. Sectio G, Ius.” 2019, vol. 66, z. 1, s. 208 i nn.

33 J.T. Ulak, Hakubō period [w:] Encyclopedia Britannica, www.britannica.com/art/Japanese-art/ Hakuho-period (dostęp: 12.02.2021). Kodyfikacja była wynikiem wysłania przez Japonię pierwszych poselstw do Chin. Normowała ona materię z zakresu prawa administracyjnego, podatkowego i karnego, a także zawierała elementy prawa cywilnego. W porównaniu do recypowanego w Europie prawa rzymskiego ritsuryō nie wyróżniało prawa prywatnego. W wyniku kodyfikacji doszło do transformacji i centralizacji systemu prawnego, który uprzednio miał charakter nieoficjalny i wywodził się z niepisanego prawa, opierającego się na systemie klanowym i sądownictwie. Prawo przestało cechować się fragmentarycznościa, która wynikała z niezupełnego i rozproszonego implementowania konstrukcji prawnych od państw sąsiednich. Klany (氏) w społeczeństwie japońskim stanowiły zbiorowości, które składały się z wielopokoleniowych rodzin, na czele których stał wódz klanu.

34 Y. Noda, Introduction..., s. 22. 
rzecz podatku od ziem uprawnych dla cesarza. Przed reformą Taika władza cesarza oraz pozycja arystokracji mogła jedynie w sposób jednostkowy wpływać na potężne majątki prywatnych rodów. Przepis art. 1 edyktu wprowadził istotną zmianę systemowa, zgodnie z którą cała ziemia japońska i jej ludność stały się własnością cesarza (domeny publicznej) i powinny być przez niego kontrolowane. Z prawnego punktu widzenia była to swoista i powszechna nacjonalizacja, a jednym z jej celów stało się całkowite zlikwidowanie prawa do własności prywatnej gruntów. Co więcej, w świetle edyktu każdy poddany stał się cesarską własnością, zatem miało miejsce zjawisko masowego uprzedmiotowienia ludności japońskiej. W związku z powyższym system prawa prywatnego („prywatnej ziemi prywatnych ludzi”; 私地私民制) stał sie wyjątkiem, a zasada był system prawa publicznego („publicznej ziemi publicznych ludzi”; 公地公民制). W gestii państwa leżało rozdzielenie ziemi wśród ludności (uwzględniało ono położenie poszczególnych rodów) i utworzenie systemu poboru podatków. Współcześnie podważa się jednak charakter prawny i egzekwowalność tego przepisu, sugerując, że miał raczej charakter ideowy i nie przenikał w sposób intensywny do społeczeństwa japońskiego ${ }^{35}$.

Kodeks Taihō (大宝律令), stanowiący kontynuację reformy Taika, był dekretem cesarskim, który został promulgowany w 701 r. i zamknął okres przejściowy tworzonego porządku prawnego w Japonii ${ }^{36}$. Budowa Taihō składała się z 17 zwojów napisanych znakami chińskimi, które przedstawiały fonetyczny zapis języka japońskiego. Opisywany Kodeks można podzielić na część ritsu (律; dosł. „prawo”) składająca się z 6 zwojów, które regulowały materię penalną, oraz część ryō (令; dosł. „rozkaz”) ujęta w 11 zwojach, zawierająca m.in. normy prawa administracyjnego, cywilnego i procesowego ${ }^{37}$. Taihō położyło fundamenty pod praworządność w Japonii, gdyż stało się pierwszą, podstawową regulacja prawną, która objęła swym zasięgiem normowania całe państwo, jednocześnie rozwijając centralizację władzy w ramach systemu ritsuryō, a także wartości etyki konfucjańskiej ${ }^{38}$.

Źródłem inspiracji i zmian dla tej reformy był chiński kodeks Yonghui (chiń. 永徽 律令) z 651 r., wprowadzony przez chińskiego cesarza Gaozong (chiń. 唐高宗) z dynastii Tang, a także zrewidowane rozwiązania systemowe i obowiązujące już na terenach Japonii przepisy. Porównując regulacje wprowadzone w Chinach i Japonii,

35 T. Yoshimura (吉村武彦), いわゆる「公地公民制」は存在したか, 古代史の新展開, [iwayuru 'kōchi kōmin-sei' wa sonzai shita ka, kodai-shi no shin tenkai], Tokio 2005, s. 81 i nn. 36 A. Watanabe (渡辺晃宏), 平城京と木簡の世紀 [heijō kyō to mokkan no seiki], 日本の歴 史04 [Nippon no rekishi 04], Tokio 2001, s. 45 i nn. Jak wskazują ówczesne źródła historyczne, kodyfikacja była nazywana wprost jako „nowe prawo” czy też „nowy rytuał”.

$37\lceil$ 大宝律令」[Taihō ritsuryō] [w:] 国史大辞典・日本大百科全書・改訂新版世界大 百科事典, [kokushi dai jiten. Nippon-dai hyakka zensho. kaitei shinpan sekai dai hyakka jiten], https://japanknowledge.com/introduction/index.html (dostęp: 12.02.2021).

38 S. Yasutoshi, K.L. Reeves, The ritsuryō state [w:] Routledge Handbook of Premodern Japanese History, ed. K.F. Friday, New York 2017, s. 84 i nn. 
można wskazać na co najmniej dwie zasadnicze różnice. W odróżnieniu od chińskich przepisów o obsadzaniu stanowisk państwowych decydowały pozycja społeczna i status nadawany wraz z urodzeniem, a nie zasługi i stopień wykształcenia. Takie rozwiązanie wynikało wprost $z$ utrwalonej tradycji japońskiej. W kodeksie Taihō odrzucono również chińską doktrynę filozofii politycznej tzw. mandatu niebios (chiń. 天命; dosł. „wola nieba”), uzasadniająca rządy monarsze cesarza, gdyż wynikające z niej założenia stały w opozycji do japońskiej mitologii i statusu władcy. Według chińskiego wzorca niebo stanowiło ucieleśnienie porządku wszechświata i nadawało prawo do rządzenia państwem jedynie cesarzowi, który odznaczał się odpowiednio wysokimi cnotami i standardami ${ }^{39}$. Klęski naturalne mogły więc być interpretowane przez Chińczyków jako utrata mandatu niebios z uwagi na niegodność władcy do sprawowania władzy cesarskiej i skutkować jego detronizacja. Ze względu na linię dynastyczną, więzy krwi i ugruntowaną pozycję prezentowana filozofia musiała zostać odrzucona w Japonii. Cesarz był uosobieniem boskości, zaś jego rządy legitymizowało pochodzenie, a nie cnoty i sposób postępowania. Sakaue Yasutoshi słusznie podsumowuje, że współcześnie historycy akcentują wielość występujących różnic w obydwóch regulacjach oraz punktów „rozchodzenia się” rozwiązań japońskich względem chińskich pierwowzorów. Świadczyło to o prowadzeniu niezależnej polityki. Zarówno Taihō, jak i późniejsza kodyfikacja Yōrō (飬老律令) ${ }^{40}$ wpisują się explicite w ten ostrożny nurt adaptacji wzorców chińskich ${ }^{41}$.

Taihō wprowadziło dwie podstawy władzy w postaci Departamentu Kultu Jingi-kan (神祇官) oraz Departamentu Państwa Daijö-kan (太政官). Pierwszy z organów zajmował się rozpoznawaniem spraw związanych ze sferą świętości oraz miał wyższa pozycję ustrojowa, co wyrażało się w pierwszeństwie przed Daijō-kan. W kognicji drugiego z departamentów leżały wszelkie sprawy świeckie. Całe państwo zostało podzielone na prowincje kuni (国), w których rządzili wyznaczeni przez rząd centralny urzędnicy kokushi (国司). W każdej z prowincji urzędnicy (gubernatorzy) byli zhierarchizowani według czteropoziomowego systemu rankingowego shitōkan (四等官), wyodrębniającego jeszcze poszczególne posady biurokratyczne ${ }^{42}$. Jednostką organizacyjna poniżej poziomu prowincji był gun (郡), który można przetłumaczyć jako dystrykt, powiat lub dzielnicę. Gunami zarządzali urzędnicy gunji (郡司) - odpowiadali oni przede wszystkim za pobór podatków, przydzielanie gruntów, utrzymywanie porządku publicznego i ewidencjonowanie ludności. Kolejne mniejsze podziały jednostek organizacyjnych były zróżnicowane w zależności

39 K. Szczepanski, What is China's Mandate of Heaven?, 1.08.2019, https://www.thoughtco.com/ the-mandate-of-heaven-195113 (dostęp: 12.02.2021).

40 Kodyfikacja Yōrō została wprowadzona w 718 r. w celu unowocześnienia i poszerzenia zakresu regulacji prawnej systemu ritsuryō.

41 S. Yasutoshi, K.L. Reeves, The ritsuryō state..., s. 87.

42 H.A. Dettmer, Der Yörō-Kodex. Die Gebote. Einleitung und Übersetžnng des Ryō no gige, Teil 1, Bch. 1, Wiesbaden 2009, s. 2-3. 
od położenia geograficznego i stopnia zaludnienia. W większości przypominały one układ małych miast i wiosek z gospodarstwami i domami, nad którymi pieczę sprawował wódz pełniący funkcję zbliżoną do dzisiejszego wójta ${ }^{43}$.

\section{Okres Nara (奈良時代)}

W ciagu kolejnych stuleci struktury władzy Japonii zmieniały się. W okresie Nara, trwającym od 710 r. do 784 r., narodził się japoński feudalizm, w którym wzorzec prawa chińskiego połączono z japońskimi zwyczajami i prawami zwyczajowymi. Wynikająca z systemu prawnego supremacja cesarska została osłabiona na skutek stale zmniejszającego się dochodu narodowego, co z kolei wynikało z nieefektywnej polityki fiskalnej oraz centralnego systemu podziału i zarządzania ziem ${ }^{44}$. We wskazanym czasie do rodzimych wierzeń japońskich zaczęły przenikać intensywnie buddyzm i taoizm. Wchodzące w skład systemu ritsuryō kodyfikacje oraz zbiory prawne stanowiły przedmiot szerokich nowelizacji, uzupełnien, aktów wykonawczych, precedensów i zaleceń, które można zbiorczo nazwać jako kyakushiki (格式) ${ }^{45}$. Niekiedy powodowały one de facto zmianę istoty wielu istniejących instytucji prawnych, a także wprowadzały w życie rozwiązania sprzeczne z anachronicznym ritsuryō. Ówcześnie granica pomiędzy derogacją a modyfikacją normy prawnej nie była ostra ${ }^{46}$. W rzeczywistości tworzono odmienne gatunkowo prawo, które pozornie tylko nowelizowało i uaktualniało ritsury $\overline{0}^{-47}$. Zaczęto odstępować od przyjętej zasady własności publicznej, wprowadzając tym samym rozwiązania prawne służące rozwojowi własności prywatnej.

Postępująca w okresie Nara prywatyzacja gruntów państwowych zwanych kokugaryō (国衙領) zaczęła osłabiać władzę centralną opartą na systemie poboru podatków handen shïju sei (班田收受制), który wynikał bezpośrednio z praw ritsuryo ${ }^{-48}$. Doprowadziło to do pojawienia się tzw. shöen (荘園; 庄園), a więc gruntów stanowiących prawo własności prywatnej. Niejednokrotnie podlegały one różnym podstawom prawnym i mieściły się poza kontrolą władzy centralnej, a przyczyną takiego stanu rzeczy było m.in. zjawisko akumulacji władzy w wielu odrębnych ośrodkach oraz

43 Y. Yoneda (米田雄介), 郡司の研究 [gunji no kenkyū], (丵書 · 歴史学研究) [sōsho. rekishigaku kenkyū], Tokyo 1976, s. 72 i nn.

44 J. Tubielewicz, Historia Japonii, Wrocław 1984, s. 75 i nn.

45 M. Hayakawa (早川万年), 三代格式 [san dai kakushiki] [w:] T. Abe (阿部猛) et al., 日本古 代史研究事典, Tokyo 1995, s. 286 i nn.

46 J. Tubielewicz, Historia Japonii..., s. 106 i nn.

47 Ibidem, s. 125 i nn. Japonia otrzymała miano „państwa opartego na kodeksach”, a z czasem, gdy prawo przestało odpowiadać japońskim potrzebom obrotu, zaczęto tworzyć nowe i bardziej praktyczne regulacje.

48 Ibidem, s. 113 i nn. 
wspomniany wyżej konflikt pomiędzy poszczególnymi normami prawnymi. Wraz z upływem czasu, na skutek wprowadzanych reform, shōen stały się rozległymi posiadłościami w całej Japonii ${ }^{49}$. Właścicielom tego typu gruntów przysługiwały ulgi lub zwolnienia podatkowe. Działalność przekupnej służby państwowej i wpływowych przedstawicieli japońskich rodów prowadziła do masowych nadużyć i wypaczania istoty praw. Dlatego pomimo ogólnej dostępności i możliwości kupna shōen w wyższych urzędach w praktyce nabywać je mogli tylko zamożni Japończycy ${ }^{50}$. Słuszny wydaje się pogląd, że konfucjańskie ideały, wyrażające się w wielu normach etycznych, nie stanowiły żelaznej bariery dla działań społeczeństwa japońskiego. W sytuacjach napięć pomiędzy różnorodnymi normami społecznymi nie zawsze dochodziło do wypracowania kompromisu czy przyjęcia rozsądnego stanowiska. Niezasadne jest więc nadmierne upraszczanie wizji Japonii poprzez idealizację czy mityzację rzeczywistych wydarzeń, co często prowadzi do błędnego założenia o rzekomym stanie kilkusetletniej harmonii. Co więcej, normy konfucjańskie nie stanowią niezmiennego w czasie zbioru, jak również istnieje wiele różnych szkół działających w ramach tego systemu filozoficzno-religijnego.

Wraz ze zmieniającą się rzeczywistością od X w. pogłębiała się utrata efektywności systemu ritsuryō na niekorzyść urzędującego dworu cesarskiego ${ }^{51}$. Rzeczywisty upadek tejże regulacji systemowej nie oznaczał automatycznej derogacji kodeksów nadal obowiązujących w jej ramach ${ }^{52}$. Prywatyzacja ziem spowodowała wzrost pozycji poszczególnych klanów oraz bogacenie się szlachty, która chętnie nabywała grunty shöen i eksploatowała ziemie za pomoca siły roboczej niewolników nubi (奴婢) lub chłopów nōmin (農民). Próby powstrzymania tego negatywnego procesu zakończyły się fiaskiem, a zdaniem Jolanty Tubielewicz rządzący wpadli w swoisty „zaklęty krąg” w postaci samonapędzającego się uszczuplania wpływów fiskalnych i osłabiania władzy centralnej ${ }^{53}$.

W międzyczasie klany na prowincjach, zyskujące coraz większe znaczenie, zaczęły dokonywać zbrojeń i konkurować między sobą w celu poszerzenia wpływów, majątków i gruntów. Skutkowało to utworzeniem sporej liczby wojowniczych ugrupowań bushidan (武士団), których funkcjonowanie opierało się na systemie wasalnym. Podobnie jak w większości krajów europejskich, również w feudalnej Japonii obowiązywała zasada, zgodnie z którą właściciel ziemi wchodził w osobisty i bezpośredni

\footnotetext{
49 Ibidem, s. 77 i nn.

50 Y. Noda, Introduction..., s. $25 \mathrm{i}$ nn.

51 J.W. Hall, Japonia: od časów najdawniejszych do džisiaj, tłum. K. Czyżewska-Madajewicz, Warszawa 1979, s. 30 i nn. W XI w. istniały ruchy zmierzające do przywrócenia systemu ritsuryō, jednakże upadły z uwagi na przestarzały wzorzec, który nie pasował do zmieniającego się systemu feudalnego i nowo powstałej klasy samurajów. Warto także nadmienić, że niektóre instytucje omawianego systemu przetrwały aż do $1868 \mathrm{r}$.

52 K. Nagahara (永原慶二), 日本封建社会論 [新装版], Tokyo 2001, s. 49 i nn.

53 J. Tubielewicz, Historia Japonii..., s. 114 i nn.
} 
stosunek zwierzchni z wasalem. Dlatego też m.in. siogun, a więc ówcześnie posiadający stopień wojskowy, dowodzący armią cesarską mógł rościć swoje prawa względem podległych mu wasali, zwanych gokenin (御家人), ale nie zyskiwał z tego tytułu jakichkolwiek uprawnień feudalnych wobec wasali swoich gokenin.

Załamanie systemu handen shüju sei, dominacja shöen i wzmocnienie prowincji doprowadziły do pogłębiającego się kryzysu władzy i ostatecznie do znacznego ograniczenia rządów administracji centralnej oraz wpływów cesarskich w reorganizowanym państwie. W Japonii pogłębiała się różnorodność prawna. Spadek prestiżu, jakim dotychczas cieszyły się Chiny, a także ujawniający się w coraz większym stopniu problem z dostosowaniem chińskich wzorców kulturowych do rodzimych potrzeb stały się dodatkowym impulsem narodowotwórczym w Japonii. W związku z tym w społeczeństwie japońskim dokonały się liczne zmiany. Oparty na chińskich znakach system man'yōgana (万葉仮名), będący najstarszym fonetycznym zapisem języka japońskiego (utworzony w $\mathrm{V}$ w. n.e.), został zastapiony utworzonym od podstaw japońskim pismem kana (仮名), a więc sylabariuszami hiraganą (ひらがな) i katakaną (カタカナ) 54 . Analizując sposób dokonywania recepcji zagranicznych wzorców do Japonii, należy zwrócić uwagę, że in genere odbywała się ona w sposób wybiórczy, stopniowy i naturalnie związany z geopolitycznym rozłożeniem sił ${ }^{55}$. W związku ze zmieniającymi się potrzebami społecznymi ad hoc tworzono liczne pozakodeksowe urzędy ryöge no kan (令外官), które w perspektywie czasu traciły na znaczeniu wskutek zmieniających się warunków społecznych ${ }^{56}$. W kręgach arystokratycznych doszło do rozkwitu kultury japońskiej, a buddyzm zyskał miano zjawiska masowego.

\section{Czasy średniowiecznej Japonii $(1185-1603)^{57}$}

1. Wprowadzenie ustroju siogunatu

Pod koniec XII w. wybuchła wojna Gempei (源平合戦) o przyszłe panowanie nad Japonią pomiędzy rządzącym klanem Taira (平氏) i klanem Minamoto (源). Zakończyła się ona w 1185 r. w wyniku przegranej bitwy morskiej w zatoce Dannōra (壇ノ浦) w związku ze śmiercia młodego cesarza Antoku (安德天皇). Wydarzenie to umożliwiło dojście do władzy Yoritomo Minamoto (源頼朝) i rozpoczęcie okresu Kamakura (鎌含幕府), który trwał do 1333 r. ${ }^{58} \mathrm{Na}$ tle dziejów japońskich był

54 J.W. Hall, Japonia..., s. 19 i nn.

55 L. Leszczyński, Japońskie recepcje prawa. Od izolacjonizmu do pragmatyzmu [w:] Japonia w oczach Polaków. Państwo - społeczeństwo - kultura, t. 2, red. J. Włodarski, K. Zeidler, Gdańsk 2009, s. 273.

56 J. Tubielewicz, Historia Japonii..., s. 131 i nn.

57 Zob. M. Cartwright, Ancient Japanese... Większość historyków zgodnie uznaje, że okres średniowiecza w Japonii trwał od 1185 do 1603 r.

58 J.W. Hall, Japonia..., s. 77 i nn. 
to czas charakteryzujący się utworzeniem nowego militarnego porządku prawnego bakufu (幕府; ,rządy spod namiotu”), zwanego także siogunatem. Strukturalnie opierał się na systemie feudalnym i wyeksponowanej pozycji dowódcy wojsk shögun (将軍) ${ }^{59}$, który w okresie Kamakura stał się dożywotnim i dziedzicznym tytułem wodza naczelnego Japonii. Pod rozkazami sioguna znajdowali się wojownicy zwani bushi (武士), a wśród nich dziedziczni i tytularni samuraje (侍), kształtujący swój etos na podstawie niepisanych zbiorów zasad etycznych, m.in. kodeksu wojownika bushidō (武士; , „droga wojownika”) ${ }^{60}$. Warto zaznaczyć, że do klasy samurajów należały także kobiety wojowniczki onna musha (女武者) ${ }^{61}$.

Z perspektywy historycznej wydaje się, że utworzenie norm postępowania skierowanych do wojowników miało na celu nie tyle kultywowanie i przestrzeganie zasad konfucjanizmu, shintoizmu czy buddyjskiego nurtu zen (禅), ile w szczególności uzależnienie lenników od pozycji sioguna i potężnych władców feudalnych daimyō (大名), posiadających rozległe, prywatne nieruchomości ${ }^{62}$. Nowa struktura władzy w postaci siogunatu spowodowała utrate przewodniej roli dworu cesarskiego i arystokracji, jednak kluczowy jest fakt, że nie doprowadziło to do ich likwidacji. Przez wiele dekad cesarze byli jeszcze w stanie utrzymać istotną część wpływów. Wprowadzona zmiana ustrojowa zdeterminowała charakter systemu władzy na ponad sześć kolejnych stuleci. System ten trwał aż do przełomu ustrojowego w 1868 r., tzw. restauracji Meiji (Meiji Ishin; 明治維新), kiedy to cesarz Mutsuhito (睦仁) zdobył pełnię władzy nad całą Japonia, pokonując ostatniego sioguna $\mathrm{z}$ rodu Tokugawa ${ }^{63}$.

Wykrystalizowany w wyniku głębokich zmian reżim feudalny cechował się podwójną naturą. Stanowił swoisty dualizm prawny wynikający z koegzystencji dwóch współistniejących ośrodków władzy. Hybrydowa struktura państwa składała się w szczególności z dominującego i zmilitaryzowanego siogunatu oraz wciąż ważnego systemowo dworu cesarskiego, czyli chottei (朝廷), w historycznej stolicy Japonii Heiankyo $\overline{0}^{64}$ (平安京) z cesarzem na czele ${ }^{65}$. Pierwszy opierał się na prawie bukehō (武家法) normującym klasę samurajów i wojskowe rządy bakufu. Podstawą

59 Zarówno etymologia nazwy „sioguna”, jak i sama ta instytucja zostały zaczerpnięte z wzorca chińskiego. Doniosła rola dowódcy, którą zaimplementowano w Japonii, istniała bowiem wcześniej w Chinach (jiāngjūn, chiń. 將軍 lub z̧hōng jūn jiāng, chiń. 中軍將). Jednakże w Państwie Środka siogun nigdy nie zdobył tak silnej pozycji społeczno-politycznej jak w Japonii.

60 Por. L.G. Perez, The History of Japan, Westport 1998, s. 35.

61 Ibidem; zob. też: Tomoe Gozen (巴御前) i Nakano Takeko (中野竹子).

62 J. Tubielewicz, Historia Japonii..., s. 159 i nn.

63 W tamtym okresie, pod wpływem nacisków cywilizacji zachodniej, doszło do otwarcia Japonii na świat zewnętrzny. Zniesiono zakazy podróżowania, a intensywna okcydentalizacja Japonii oraz wprowadzane dynamicznie reformy rozpoczęły okres Meiji, tzw. Erę Światłych Rządów (Meiji-jidai; 明治時代).

64 Później nazwano ją Kioto (京都市) i pełniła funkcję miasta stołecznego w latach 794-1868.

65 M. Dean, Japanese Legal System: Text, Cases and Materials, $2^{\text {nd }}$ ed., London 2003, s. 74. Oba ośrodki władzy zostały zmienione dopiero w $1868 \mathrm{r}$. 
drugiego było prawo kugehō (公家法), które pochodziło od dworu cesarskiego zdominowanego przez japońską klasę arystokratyczną, w tym powiązane z nim sądy cesarskie i kancelarie. Normowało ono podległych cesarzowi arystokratów, duchownych świątyń i sanktuariów oraz gubernatorów prowincjonalnych ${ }^{66}$. W początkowym okresie uformowania siogunatu nie istniało właściwe, określające go prawo, które uwzględniałoby nowy porządek, a kugehō nie było dostosowane do wprowadzonej zmiany ustrojowej. Dlatego w owym czasie źródłem norm prawnym dla bakufu były wydawane rozkazy i rozstrzygnięcia sądowe, opierające się najczęściej na uznawanych normach społecznych (w szczególności normach moralnych i zwyczajowych tworzonych i zmienianych od wieków przez wojowników), które poprzez walidację uzyskiwały status norm prawa zwyczajowego.

Z powodu niewdrożenia przez kilkadziesiąt lat odpowiednich rozwiązań systemowych, pozwalających formułować prawo stanowione w ustroju bakufu, powstał stan niepewności prawnej, w tym problem stosowania prawa względem poszczególnych rodzin samurajów. W $1232 \mathrm{r}$. wprowadzono charakteryzujący się prostym i zrozumiałym językiem kodeks Jöei (貞永式目) ${ }^{67}$, który był instrumentem zaradczym w obliczu pogłębiającego się bezładu prawnego. Zawierał znaczną część przepisów natury administracyjnej i cywilnej oraz wcielił do prawa stanowionego liczne normy prawa zwyczajowego, a także dał możliwość ustanawiania precedensów, w szczególności odnoszących się do wasali sioguna gokenin ${ }^{68}$. Wprowadzoną kodyfikację ${ }^{69}$

66 Prawo to wykształciło się w wyniku zmian społecznych w Japonii i sięga rodowodem do kyakushikei, które to wypaczyło istotę ritsuryō. Kugehō regulowało m.in. system organizacyjny państwa, kompetencje urzędników dworskich, zasady obejmowania urzędów i zasady terytorialnej władzy samorządowej. Kugehō zostało w późniejszym okresie osłabione i przyćmione przez rosnącą pozycję społeczną wojowników bushi. W tym czasie mianem kuge (公家) zaczęto określać wszystkich pracujących na dworze urzędników, a więc nie tylko z rodów arystokratycznych. Po utracie realnej władzy w państwie Dwór Cesarski zajmował się rozwijaniem kultury japońskiej i utrzymał się aż do 1868 r., kiedy to został scalony z zarządzającymi ziemiami daimyō.

67 Zwany także Goseibai Shikimoku (御成敗式目), tzw. kodeks postępowania samurajów, by1 istotnym źródłem wiedzy dla kompleksowej nauki o historii i działalności państwa japońskiego o nazwie Yusoku Kojitsu (有職故実) oraz źródłem, na którym wzorowano się w aktach prawnych późniejszych czasów, m.in. Kenmu Shikimoku (建武式目), Bunkokuhō (分国法), Buke Shohatto (武家諸法度) i Hanpo (判補).

68 Zob. Jitō [w:] Encyclopaedia Britannica, www.britannica.com/topic/jito (dostęp: 12.02.2021); Shugo [w: Encyclopaedia Britannica, www.britannica.com/topic/shugo (dostęp: 12.02.2021). Wśród wasali sioguna najistotniejszymi dla systemu feudalnego byli tzw. jito (地頭) oraz shugo (守護). Pierwsi byli dziedzicznymi administratorami ziem, którzy pobierali należności podatkowe i służyli jako lokalni sędziowie. Z czasem wyparli pochodzących z dworu cesarskiego gubernatorów prowincjonalnych do spraw cywilnych, tzw. kokushi (国司). Ci zaś zapewniali porządek i ochronę (np. cesarza), a ich pozycję można określić mianem gubernatorów wojskowych. Stanowili potężne grupy w XIV w., które zostały w późniejszym czasie scalone z pozycją panów feudalnych daimyō.

69 Normowała m.in. sposób postępowania komisarzy majątków ziemskich, gubernatorów wojskowych, sposoby rozwiązywania konfliktów, sposoby dziedziczenia czy ochronę instytucji 
powszechnie uważano za bezstronną, odpowiednio wyważoną i zawierającą zbiór uczciwych reguł postępowania ${ }^{70}$.

W literaturze przedmiotu niesłusznie marginalizuje się znaczenie trzeciego porządku prawnego tzw. honjohō (本所法), który funkcjonował równolegle z prawem bukehō i kugehō. Wraz z upadkiem systemu ritsuryō władza cesarska straciła wyłączność decydowania w sprawach sądowych i administracyjnych. Urzędnicy państwowi zostali odsunięci od możliwości egzekwowania władzy dworskiej, jednak w rzeczywistości istniało wiele wyjątków, które wynikały chociażby z pełnienia podwójnych funkcji i powiązania organizacyjnego danych siedzib z głównymi organami administracyjnymi. Honjohō regulowało m.in. sposób sprawowania kontroli przez wpływowe rodziny szlacheckie i reprezentantów instytucji religijnych nad posiadłościami shōen, zasady właściwości miejscowej i rzeczowej oraz wiele innych powiązanych z shōen stosunków prawnych, które wiązały się z prowadzoną na nich działalnościa gospodarczą (w tym np. z zobowiązaniami umownymi dotyczącymi gier i zakładów, a więc wykonywania działalności hazardowej) ${ }^{71}$.

Honjohō składało się zarówno z prawa stanowionego o ogólnokrajowym charakterze, które wyznaczało ogólne ramy regulacyjne, jak i praw zwyczajowych właściwych dla miejsca położenia shōen oraz praw stanowionych przez gubernatorów prowincji. Z tego powodu poszczególne dwory znacząco różniły się pod względem prawa obowiązującego na ich terenach. Prawa zwyczajowe były charakterystyczne dla poszczególnych regionów Japonii. Na lokalne potrzeby, wśród występujących tam zbiorowości, wykształcono normy prawne, które opierały się na zwyczajach i ogólnym ich uznaniu za prawo obowiązujące. Prawa zwyczajowe wpisują się w szersze pojęcie prawa ustnego, a więc niepisanego (fubunhō; 不文法), zwanego także w Japonii prawem niegramatycznym. Warunkiem uznania danej normy społecznej za normę prawną jest jej odpowiednia dla danego systemu prawnego walidacja. Przy czym w omawianych czasach Japonii, podobnie jak w wielu ówczesnych państwach, prawo stanowione nie określało w sposób zupełny katalogu źródeł prawa, ani też procesu uznania za normę prawną. W związku z tym każdą sytuację i ewentualne obowiązywanie prawa niepisanego należało indywidualnie zbadać.

religijnych; zob. Nihon University School of Law w Tokio, 御成敗式目について [go seibai shikimoku ni tsuite], https://www.law.nihon-u.ac.jp/library/htmls-201901/about_us.html (dostęp: 12.02.2021); J. Tubielewicz, Historia Japonii..., s. 164 i nn.

70 Rozwiązania przyjęte w kodyfikacji zostały zaakceptowane także przez arystokrację dworską i przedstawicieli religii, a więc tych, którzy nie byli wasalami.

71 H. Shiono, Administrative Guidance in Japan (Gyosei-Sbido), „International Review of Administrative Science” 1982, vol. 48, issue 2, s. 239 i nn.; na temat działalności hazardowej por. M. Yoshimura (吉村昌輝), 鎌含本所法における博奕について [Kamakura Honjo hō ni okeru bakueki ni tsuite] [w:] Y. Yasuyuki (吉田靖之), 法学政治学論究: 法律, 政治, 社会 [hōgaku seiji-gaku ronkyū: hōritsu seiji shakai], no. 43, Tokio 1999, s. 575 i nn. 
Prawa zwyczajowe, w odróżnieniu od prawa stanowionego, wykształciły się w sposób organiczny i oddolny, gdyż wynikały z codziennych relacji międzyludzkich.

$\mathrm{Na}$ mocy honjohō utworzono tzw. honjo (本所; główne biuro), którego celem było m.in. rozwiązywanie sporów i spraw dotyczących określonych gruntów, na których obowiązywało wiele różnych tytułów prawnych. Honjo był organem sui generis o cechach quasi-sądowych, administracyjnych, karnych i policyjnych. Rozprawy odbywały się z udziałem stron i wyspecjalizowanych urzędników, a podstawa rozstrzygnięć umożliwiała sporą swobodę decyzyjna. Mianem honjo określało się także persony (w tym panów dworu) mające realną władzę i wpływy w centralnym honjo, które wykorzystywały swoje uprawnienia do ochrony dworów (w szczególności przed rządami sioguna) w zamian za odpowiednie korzyści.

Honjohō odgrywało istotną rolę w okresie Kamakura, a więc w pierwszym utworzonym w Japonii siogunacie, natomiast w późniejszym okresie zostało ograniczone przez regulację Taibon Sankajo (大犯三箇条) i rozpowszechnienie umów jïtouke (地頭請). Następnie wraz z postępującym rozszerzaniem władzy sioguna na całe terytorium Japonii i zdominowaniem przez prawo bukehō, któremu honjohō służyło jedynie subsydiarnie, zostało ono całkowicie wcielone do porządku bakufu ${ }^{72}$. Honjohō zniesiono po rozwiązaniu systemu kontroli tzw. ziem publicznych i majątków prywatnych shōen kōryō sei (荘園公領制). W ówczesnej Japonii istniały także inne regulacje prawne, które normowały bezpośrednio wybrane aspekty spraw, np. relacje w klasie społecznej rzemieślników czy kupców ${ }^{73}$.

\section{Rozwój japońskiego systemu zarządzania gruntami}

$\mathrm{Na}$ obszarze prawa prywatnego istotne znaczenie gospodarcze należy przypisać działalności tradycyjnej, wielopokoleniowej japońskiej rodziny w ramach struktury prowadzonych gospodarstw ie (家). Gospodarstwa te dzieliły się na główne gospodarstwa domowe honke (本家) oraz znajdujących się w pobocznej linii względem nich tzw. bunke (分家), nazywanych także makkee (末家), które wynikały z naturalnych odgałęzień rodzinnych lub stosunków podległości służby ${ }^{74}$. W przedstawionym układzie głowa rodziny honke była nominalnie właścicielem gruntów i znajdowała się na szczycie skomplikowanej i wielowarstwowej struktury sprawowania władztwa nad nieruchomościami ${ }^{75}$. Gospodarstwa ie zamieszkujące ten sam obszar grupowały się w zorganizowane związki zwane dōzokudan (同族団). Kizaemon Ariga stwierdza, że gospodarstwa linii rodzinnych bunke mogły również korelować z innymi bunke, dla których stanowiły honke, co naturalnie wynika wprost z faktu istnienia stosunków

72 N. Haga (羽下德彦), 点景の中世一武家の法と社会, Tokyo 1997, passim.

73 Por. S. Hamamoto, Law and Politics in Japan, Kyoto 2012, 17.05.2012, www.hamamoto.law. kyoto-u.ac.jp/kogi/2012/2012KUINEP/120517before_Meiji.pdf (dostęp: 12.02.2021).

74 K. Ariga, The Issue of Hierarchy in Japanese Social Structure, transl. J.E. Roberson, ,Japanese Review of Cultural Anthropology" 2015, vol. 16, s. 30 i nn.

75 K. Nagahara (永原慶二), 日本封建社会論..., s. $130 \mathrm{i} n$ n. 
pokrewieństwa. Z tego powodu nowe gospodarstwa dołączające do danych związków miały wpływ na istniejące już układy, gdyż w zależności od konkretnych warunków gospodarstwo mogło należeć do więcej niż jednego zwiazzu. Dōzokudan zajmował zazwyczaj obszar w obrębie jednej wioski. W ramach ustalonych stosunków danej grupy gospodarstwa ie koegzystowały ze sobą i udzielały sobie wzajemnie wsparcia, a wśród nich często dominowało zazwyczaj jedno bonke ${ }^{76}$. Gospodarstwa oraz ich związki odgrywały ważną rolę systemowo-ekonomiczną w feudalnej Japonii.

Wejście w życie kodeksu Jōei rozwiązało problem wielowarstwowego i niewydajnego systemu kontroli nieruchomości shöen kōryō sei ${ }^{77}$. Nowa regulacja daż̇łła do zharmonizowania norm prawnych w zakresie wielopoziomowych, prywatnych i publicznych relacji związanych z gruntami, pracującymi na nich chłopami oraz wynikających z tych dwóch relacji poszczególnych praw (np. pożytków z nieruchomości). Wprowadzone na podstawie reformy ujednolicenie i uporządkowanie wskazanych norm prawnych nosiło miano ichienchigyō (一円知行). Złożone było z dwóch typów: jöbun (上分), a więc tzw. części górnej, która dotyczyła przychodów uzyskiwanych z nieruchomości i pracujących na niej chłopów (w postaci np. corocznej daniny, podatków, utrzymywania określonej relacji z podmiotami publicznymi), oraz shitaji (下地), czyli tzw. części dolnej, fundamentu będącego samą nieruchomością ${ }^{78}$. Ichienchigyō stosowano obszernie we wschodniej części feudalnej Japonii. W jego zakresie doniosłe znaczenie należy przypisać zawieranym na poziomie lokalnym umowom kreującym stosunek prawny jitōuke (地頭請), który powstawał pomiędzy władcą feudalnym shöen ryōshu (荘園領主) ${ }^{79}$ a zarządcą ziemi jito (地頭).

Zarządcy jitō byli wybierani spośród wasali sioguna (gokenin), a do ich zadań należało m.in. administrowanie majątkami ziemskimi, do których zostali przydzieleni, i pobieranie z nich należności. Umowy jitōuke nie przenosiły prawa własności, ale uprawniały i zobowiązywały władców feudalnych do zarządu nieruchomościa, sprawowania nad nią kontroli i zbierania pożytków, które następnie miały być oddawane jitōo. W zamian feudał shōen ryōshu otrzymywał od jitō z góry określoną sumę pieniędzy w formie opłaty. Dla władcy feudalnego był to stały coroczny dochód, uzyskiwany niezależnie od ilości dokonanych zbiorów. Z kolei zarządca ziem sioguna mógł osiagnąć większy zysk w postaci pewnego ułamka ceny za uprzednio otrzymane pożytki, które następnie podlegały sprzedaży. W zależności od umowy miał jednak prawo ponosić ryzyko w postaci niekorzystnego ukształtowania cen produktów pod wpływem kreowanego w gospodarce popytu i podaży oraz

\footnotetext{
76 K. Ariga, The Issue of Hierarchy...

77 Shöen köryō sei zawierał korelacje pomiędzy majątkami prywatnymi, w tym religijnymi, cesarskimi, dworskimi oraz dedykowanymi urzędami. Jego wprowadzenie datuje się na połowę XI w., a największy rozkwit na początek XII w.

78 K. Nagahara (永原慶二), 日本封建社会論..., s. 188 i nn.

79 Nazwa shōen ryōshu używana jest przez współczesnych historyków i nie była znana w ówczesnych czasach.
} 
otrzymania niewystarczającej ilości lub jakości zebranych w sezonie pożytków ${ }^{80}$. W zachodniej części Japonii chłopi wzmocnili swoje więzi terytorialne, tworząc silne, lokalne zbiorowości, które często umożliwiały im skuteczne opieranie się kodeksowej regulacji Jōei ${ }^{81}$. Jest to kolejny jaskrawy przykład istniejącego w Japonii partykularyzmu prawnego.

\section{Zmiany ustrojowe i dalszy rozwój japońskiego systemu prawa}

Warto ponownie podkreślić, że w odniesieniu do krajów azjatyckich, w szczególności zaś do Japonii, należy dokonać rozróżnienia pomiędzy władzą formalną, wynikająca z ustrojowych norm prawnych, a władzą realną, czyli faktycznie dzierżoną ${ }^{82}$. Przed wprowadzeniem bakufu w historii pojawiali się tzw. ekscesarze, którzy formalnie rezygnowali ze swego stanowiska, aby zabezpieczyć często nieletnim potomkom objęcie tytułu cesarza oraz aby sprawować realną władzę w ich imieniu. Cesarz reprezentował sferę sacrum, a linia cesarska biegła nieprzerwanie. Dla społeczeństwa japońskiego stanowiło to trwały symbol państwowości, reprezentacji narodu, tradycji i kultu religijnego. Cesarz stanowił nienaruszalny fundament, a jego systemowe usunięcie byłoby bardzo trudnym wyzwaniem. Feudalnej Japonii nie należy bowiem utożsamiać jedynie $z$ władzą centralną, lecz także $z$ istniejącym partykularyzmem prawnym, pewnym stopniem autonomii poszczególnych prowincji pomimo wpływów regionalnej administracji oraz skomplikowanymi relacjami podmiotów, które wynikały z wielości oddziałujących ze sobą norm społecznych.

Adekwatna dla warunków japońskich wydaje się chińska maksyma „挟天子以 令诸侯”, oznaczająca, że należy kontrolować cesarza, aby móc wydawać rozkazy książętom w jego imieniu. Zwrot ten należy rozumieć jako sprawowanie władzy nad innymi zgodnie $z$ własną wolna, pozornie tylko odzwierciedlając wolę cesarza. Cesarz reprezentował sferę świętości i mimo że pozycja sioguna była dominująca, to cesarz stanowił jedno ze źródeł legitymacji jego władzy. Słusznie wywodzi Kenneth Henshall, że istniały rody, które byłyby w stanie zmobilizować środki konieczne do eliminacji cesarza i zdobycia władzy, ale nie oznaczało to a limine możliwości zapewnienia im stabilnych i centralnych rządów. Posiadaczami samoistnymi większości gruntów rodowych, na podstawie odrębnych stosunków prawnych, byli m.in. drobniejsi władcy ziemscy, tzw. jizamurai (地侍) ${ }^{83}$, którzy zajmowali się zarządem gruntów. Sprawowanie kontroli nad znacznie oddalonymi od stolicy ziemiami było wymagające dla wszystkich rodów (w tym podległych siogunowi potężnych

${ }^{80}$ K. Nagahara (永原慶二), 日本封建社会論...

81 Ibidem.

82 K. Henshall, $A$ History of Japan ..., s. 29 i nn.

83 Jizamurai pojawili się z początkiem XIII stulecia w wyniku odejścia od prawa zwyczajowego primogenitury (dziedziczenia majątku przez najstarszego syna) na rzecz podziału przez władców ziem między swoich synów. 
władców feudalnych daimyō $)^{84}$. Na przestrzeni wieków walczono o pozycję sioguna, która zapewniałaby realną władzę w państwie, gdyż obalenie cesarza było w takim układzie niepotrzebne. Znacznie korzystniejsza dla osób chcących dzierżyć władzę okazywała się możliwość kontrolowania sioguna i wpływania na niego za pomocą różnych urzędów i zabiegów politycznych ${ }^{85}$.

W średniowieczu porządek prawny bakufu zapewniał skuteczną kontrolę nad narodem japońskim. Biorąc pod uwage przesłanki historyczne, należy rozróżnić Siogunat Kamakura, Siogunat Ashikaga oraz Siogunat Tokugawa.

Siogunat Kamakura cechował się koegzystowaniem władzy sioguna i wojowników bushi z dworem cesarskim (chōtei). Był to reżim samurajski, w ramach którego siogun stanowił rdzeń, a rodzina cesarska kręgosłup państwa. Dwór zatracał ówcześnie odgrywanie znaczącej roli w państwie.

Siogunat Ashikaga (室町幕府), zwany także Muromachi (室町幕府), istniał od ok. 1336 do 1573 r. Charakteryzował się całkowitym zaćmieniem władzy cesarskiej, a także zdominowaniem dworskich posiadłości ziemskich i porządku prawnego kugehō i honjohō na rzecz praw reżimu wojskowego bukehōo ${ }^{86}$. Od tych czasów siogunat objął supremację w ustroju państwa japońskiego.

Okres Muromachi, charkteryzujący się dominacją klas walczących, naznaczony był również licznymi wojnami domowymi lub politycznymi, w rezultacie których wprowadzono liczne reformy praw gruntowych. Sytuację ówczesnej Japonii dobrze odzwierciedla początek omawianego okresu, tj. lata 1336-1392 określane mianem Nanbokuchō jidai (南北朝時代), kiedy to rywalizowały z sobą dwa dwory cesarskie: północny z siedzibą w Kioto, którego cesarze byli pretendentami uzależnionymi od siogunatu Ashikaga, oraz południowy z siedzibą w Yoshino (吉野郡), rządzony przez cesarza Go Daigo (後醍醐天皇). Trwające ponad 50 lat starcie dwóch ośrodków władzy zakończyło się zwycięstwem siogunatu i północnego dworu cesarskiego. W wyniku prowadzonych bitew rodzina cesarska utraciła znaczną część shōen na rzecz wojowników, podobnie stało się z majątkami zniszczonymi w wyniku starć rodów arystokratycznych, a sam cesarz został pozbawiony możliwości sprawowania kontroli nad ziemiami publicznymi kokugaryo ${ }^{-87}$. Ponadto rządy bakufu w okresie Muromachi doprowadziły do nadmiernej eksploatacji i poborów danin

\footnotetext{
${ }^{84}$ K. Henshall, A History of Japan..., s. 29 i nn.

85 J. Tubielewicz, Historia Japonii..., s. 161 i nn. Najefektywniejsze w sprawowaniu kontroli nad cesarzem stały się dwa urzędy zwane łącznie mianem sekkan (摂関), a więc sesshō (捸政), który sprawował regencję w okresie małoletniości cesarza, oraz kanpaku (関白), będący osobistym doradcą cesarza w okresie pełnoletniości. Zgodnie z przepisami ustrojowymi cesarz podejmował decyzję po przeprowadzeniu dyskusji z kampaku, który to w wielu przypadkach był uprzednio regentem sesshō. Jednakże wskazani bliscy cesarzowi urzędnicy mogli w rzeczywistości wywierać na niego znaczny wpływ, co przez wieki służyło rządom siogunów.

${ }^{86} \mathrm{~K}$. Henshall, $A$ History of Japan ..., passim.

87 J. Tubielewicz, Historia Japonii..., s. 220 i nn.
} 
z shōen oraz wzmocnienia klas wojowników, co wiązało się z powolnym rozkładem gospodarki opartej na prywatnych gruntach ${ }^{88}$. Od 1467 do 1477 r. toczyła się wojna domowa Ōnin (応仁の乱), która rozpoczęła okres Sengoku (戦国時代; Walczących Państw). Trwał on w latach 1467-1568 i był napiętnowany nieustannymi wojnami domowymi toczącymi się pomiędzy rodami, starciami politycznymi, wstrząsami społecznymi, zbrojeniem się klasztorów i próbami osiagnięcia pełni władzy przez poszczególnych daimyō. W tym czasie w Japonii pogłębiał się chaos i fragmentacja poszczególnych regionów. Notorycznie występowało zjawisko tzw. gekokujo (下克上), oznaczające obalanie rządzących czy też sprawowanie rządów przez osoby o niższej pozycji w hierarchii społecznej ${ }^{89}$. Co więcej, wydarzenia destabilizujące władzę nie mogły zostać powstrzymane przez rządy osłabionego siogunatu.

Opisywany okres Muromachi jest również znany z utrzymywania swobodnych kontaktów Japonii z Państwem Środka, czego przykładem były m.in. wyjazdy do Chin japońskich mnichów w celach religijnych i handlowych oraz przybywanie do Japonii chińskich mistrzów rzemiosła. Pomimo odejścia od ścisłej współzależności z systemem chińskim i inspirowania się nim, w przestrzeni publicznej widoczne były wpływy tego mocarstwa, np. w poglądach filozoficznych, malarstwie i sztuce użytkowej ${ }^{90}$. W 1543 r. rozpoczął się ponad 70-letni okres Nanban bōeki (南蛮貿易; , handlu południowych barbarzyńców”), kiedy to do Japonii zaczęli przybywać m.in. portugalscy żeglarze, misjonarze i kupcy.

W okresie pomiędzy upadkiem siogunatu Muromachi a przed powstaniem siogunatu Tokugawa historycy wyróżniają okres Azuchi Momoyama (安土桃山時代), trwający od 1568 do 1600 r. Działało w nim kilka osobistości, które współcześnie uznawane sa za jedne z najwybitniejszych w całej historii Japonii. Byli to kolejno: Nobunaga Oda (織田信長), Hideyoshi Toyotomi (豊臣秀吉) i Ieyasu Tokugawa (德川家康). Każdy z wymienionych dążył do zjednoczenia Japonii, jednakże sukces w tym zakresie odniósł dopiero ostatni z nich. W wyniku zwycięstwa w decydującej bitwie pod Sekigaharą (関ヶ原の戦い) w 1600 r. ród Tokugawa zyskał hegemonię w całym państwie, dając tym samym początek okresowi Edo.

Siogunat Tokugawa (德川幕府), nazywany również siogunatem Edo (江戸幕府), trwał od 1603 do 1868 r. ${ }^{91}$ Ze względu na to, że okres ten wykracza poza ramy niniejszej pracy, nie będzie tu bliżej charakteryzowany, przy czym dla uściślenia dyskursu należy wskazać jedynie, że wykrystalizowany wówczas ostatni ustrój feudalny Japonii jest określany mianem systemu bakuban (幕藩体制). U jego podstaw wprowadzono dychotomiczną formę rządów w postaci siogunatu i zainspirowanych

88 Zob. m.in. wprowadzone w 1368 r. prawo banzei (半済; „zapłata połowy”) wzmacniające pozycje konstablów prowincjonalnych.

89 K.F. Friday, Japan Emerging: Premodern History to 1850, London 2012, s. 347 i nn.

90 J. Tubielewicz, Historia Japonii..., s. 211.

91 M. Ray, Tokugawa period [w:] Encyclopaedia Britannica, https://www.britannica.com/event/Tokugawa-period (dostęp: 12.02.2021). 
wzorcami chińskimi, częściowo autonomicznych domen feudalnych han (藩) w łącznej liczbie 276 jednostek. Poszczególne hany były rządzone przez podległych siogunowi daimyōi członków klanu, którym służyli bezpośredni wasale mający swoich własnych wasali zgodnie z ideą drabiny feudalnej. Daimyō musieli składać hołd kontrolującemu cały reżim, najwyższemu w hierarchii i utrzymującemu stała armię siogunowi ${ }^{92}$. W ówczesnym okresie niezwykle efektywny okazał się system sprawowania kontroli przez sioguna nad poszczególnymi władcami hanów. Polegał on m.in. na obligatoryjnym wysyłaniu przez tychże władców swoich spadkobierców i członków rodzin na dwór sioguna. Stanowiło to swoiste zabezpieczenie w postaci przetrzymywania zakładników, które zapewniało skuteczny posłuch. W czasie siogunatu Tokugawa została wprowadzona surowa samoizolacja Japonii, zakazująca i znosząca niemal całkowicie szeroko rozumiane wpływy zewnętrzne. Rolę cesarza ograniczono jedynie do uczestnictwa w ceremoniach sakralnych, a obywateli, klasztory i sanktuaria poddano ścisłej kontroli administracji centralnej siogunatu. Samuraje stali się najbardziej uprzywilejowaną klasę społeczną. Pomimo zjednoczenia narodu na wielu obszarach nadal występowały odmienności prawne, wynikające m.in. z wprowadzonych podziałów administracyjnych, wielości źródeł prawa i norm społecznych, które intensywnie przenikały do świadomości Japończyków i kształtowały codzienny sposób ich postępowania.

\section{Podsumowanie}

$\mathrm{Na}$ gruncie podjętych w niniejszym artykule rozważań wydaje się uzasadnione twierdzenie, że holistyczne i spójne zrozumienie japońskiego systemu prawnego, bez poznania niezbędnego kontekstu historycznego opisywanych czasów, może być nieefektywne i prowadzić do nadmiernych uproszczeń. Pomimo znacznych wpływów chińskich do XVII w., orientalna kultura Japonii zdołała wykształcić rodzime normy społeczne, które w dużej mierze przetrwały do czasów współczesnych (przy uwzględnieniu oczywistej ewolucji). Jedynie częściowo zostały one zainspirowane i oparte na wzorcu kulturowym Państwa Środka. Podejście Japończyków do obcych wpływów było w dużej mierze świadome, selektywne i kształtowało transformację oraz rozwój kultury. Należy zwrócić uwagę, że prawo japońskie jest głęboko zakorzenione i nierozerwalnie sprzężone $z$ historią i tradycją Japonii. Aż do okresu Meiji normy prawne tworzono w bardzo specyficznym, niejednolitym i dynamicznym środowisku ścierających się z sobą ośrodków władzy, czemu równocześnie towarzyszyły silne oddziaływania $z$ innymi normami społecznymi (w tym $z$ wieloma konwencjami i etyką konfucjańską). Późniejsza wykładnia i analiza ewolucji tychże

92 F.G. Notehelfer, The bakuhan system [w: Encyclopaedia Britannica, https://www.britannica.com/ place/Japan/The-bakuhan-system (dostęp: 12.02.2021). 
norm prawnych nie może być w sposób znaczący oderwana od historii i ówczesnej rzeczywistości, gdyż w przeciwnym razie okaże się nierzetelna. Kluczowe jest tu zjawisko intensywnego przenikania norm społecznych do światopoglądu Japończyków i ich codziennego życia. Brak głębszego zbadania tych norm, które współtworzyły rzeczywistość historyczną, zaburza prawidłową optykę, czyniąc realny kształt systemu japońskiego mniej uchwytnym z punktu widzenia osób wychowanych w duchu europejskiego systemu civil law.

W przyjętych ramach czasowych system prawny Japonii charakteryzuje się dużą odpornością na derogowanie wprowadzonych do niego instytucji prawnych, nawet w przypadku rozległych zmian systemowych. Wiele współczesnych urzędów wywodzi się z kilkusetletniej historii, niejako adaptując się do zmian ustrojowych bądź też istniejąc w sposób jedynie formalny z uwagi na ciagłość tradycji. Nierozerwalnie połączone z systemem prawnym Japonii pozostają także normy zwyczajowe, religijne i normy prawa zwyczajowego, których doniosłość jest uwidoczniona na poziomie lokalnym, a których geneza może sięgać daleko w przeszłość. W tym kontekście szczególne znaczenie należy przypisać regionalizacji, stopniowi autonomiczności poszczególnych obszarów i doniosłej roli rodzimych rodów.

\section{Literatura}

「大宝律令」[Taihō ritsuryō] [w: 国史大辞典 ·日本大百科全書 · 改訂新版世界大百 科事典 [kokushi dai jiten. Nippon-dai hyakka zensho. kaitei shinpan sekai dai hyakka jiten], https://japanknowledge.com/introduction/index.html (dostęp: 12.02.2021).

Aikens C., Higuchi T., Prehistory of Japan, New York - London 1982.

Ariga K., The Issue of Hierarchy in Japanese Social Structure, transl. J.E. Roberson, ,Japanese Review of Cultural Anthropology" 2015, vol. 16.

Cartwright M., Ancient Japanese \& Chinese Relations, Ancient History Encyclopedia, 27.06.2017, www.ancient.eu/article/1085/ancient-japanese--chinese-relations/ (dostęp: 12.02.2021).

Dean M., Japanese Legal System: Text, Cases and Materials, $2^{\text {nd }}$ ed., London 2003.

Dettmer H.A., Der Yōrō-Kodex. Die Gebote. Einleitung und Übersetzung des Ryō no gige, Teil 1, Bch. 1, Wiesbaden 2009.

Etymology of 'Wa', 'Yamatai' and Nippon', Heritage of Japan, www.heritageofjapan.wordpress. $\mathrm{com} /$ yayoi-era-yields-up-rice/the-advent-of-agriculture-and-the-rice-revolution/who-wasqueen-himiko/etymology-of-wa-yamatai-and-nippon/ (dostęp: 12.02.2021).

Fackler M., Japanese roots surprisingly shallow. Migrants from mainland planted new culture around 400 B.C., „The Japan Times”, 31.08.1999.

Friday K.F., Japan Emerging: Premodern History to 1850, London 2012.

Furuichi Y., 'Jomon woman' helps solve Japan's genetic mystery, NHK World - Japan, 11.06.2019, www3. nhk.or.jp/nhkworld/en/news/backstories/555/ (dostęp: 12.02.2021).

Gross domestic product (current US\$), World Bank national accounts data, and OCED National Accounts data files, The World Bank, https://data.worldbank.org/indicator/NY.GDP.MKTP.CD (dostęp: 12.02.2021). 
Grossa L., Zhao Z., Archaeological and genetic insights into the origins of domesticated rice, „Proceedings of the National Academy of Sciences of the United States of America" 2014, vol. 111, no. 17.

Haga N. (羽下德彦), 点景の中世一武家の法と社会 [tenkei no chūsei-buke no hō to shakai], Tokyo 1997.

Hall J.W., Japonia: od czasów najdawniejszych do dzৃisiaj, tłum. K. Czyżewska-Madajewicz, Warszawa 1979.

Hamamoto S., Law and Politics in Japan, Kyoto 2012, 17.05.2012, www.hamamoto.law.kyoto-u. ac.jp/kogi/2012/2012KUINEP/120517before_Meiji.pdf (dostęp: 12.02.2021).

Hayakawa M. (早川万年), 三代格式 [san dai kakushiki] [w:] T. Abe (阿部猛) et al., 日本古代 史研究事典 [Nippon kodai-shi kenkyū jiten], Tokyo 1995.

Henshall K., A History of Japan, $3^{\text {rd }}$ ed., London 2012.

Hirai N., ,shintō" [w:] Encyclopaedia Britannica, www.britannica.com/topic/Shinto (dostęp: 12.02.2021).

Hurst G.C., Japan [w:] Encyclopaedia Britannica, www.britannica.com/place/Japan/History (dostęp: 12.02.2021).

Jinam T.A., Kanzawa-Kiriyama H., Saitou N., Human genetic diversity in the Japanese Archipelago: dual structure and beyond, „Genes \& Genetics Systems” 2015, vol. 90, issue 3.

Jitō [w:] Encyclopaedia Britannica, www.britannica.com/topic/jito (dostęp: 12.02.2021).

Leszczyński L., Japońskie recepcje prawa. Od izolacjonizmu do pragmatyzmu [w:] Japonia w oczach Polaków. Państwo - społeczeństwo - kultura, t. 2, red. J. Włodarski, K. Zeidler, Gdańsk 2009.

Leszczyński L., O japońskim porz̨qdku prawnym - międry litera prawa a otwartościa norm, „Annales Universitatis Mariae Curie-Skłodowska. Sectio G, Ius.” 2019, vol. 66, z. 1.

Levi N., The Impact of Confucianism in South Korea and Japan, „Acta Asiatica Varsoviensia” 2013, nr 26.

Lu D., Japan: A Documentary History: The Late Tokugawa Period to the Present, London 1996.

Miyake M.H., Old Japanese: A Phonetic Reconstruction, $2^{\text {nd }}$ ed., Tokyo 2013.

Nagahara K. (永原慶二), 日本封建社会論 [新装版], Tokyo 2001.

Notehelfer F.G., The bakuhan system [w:] Encyclopaedia Britannica, https://www.britannica.com/ place/Japan/The-bakuhan-system (dostęp: 12.02.2021).

Ono A., Modern homonids in the Japanese Islands and the early use of obsydian: the case of Onbase Islet [w:] Human Origin Sites and the World Heritage Convention in Asia. World Heritage HEADS 3, papers 39, ed. N. Sanz, Paris - Mexico 2014.

Perez L.G., The History of Japan, Westport 1998.

Ray M., Tokugawa period [w:] Encyclopaedia Britannica, https://www.britannica.com/event/Tokugawa-period (dostęp: 12.02.2021).

Shillony B-A., 'Restoration', 'Emperor', 'Diet', 'Prefecture' or: How Japanese concepts were Mistranslated into Western Languages [w:] Rethinking Japan: Social sciences, ideology \& thought, eds. A. Boscaro, F. Gatti, M. Raveri, $2^{\text {nd }}$ ed., New York 2015.

Shiono H., Administrative Guidance in Japan (Gyosei-Shido), „International Review of Administrative Science" 1982, vol. 48, issue 2.

Shugo [w:] Encyclopaedia Britannica, www.britannica.com/topic/shugo (dostęp: 12.02.2021).

Stearns P.N., The Spread of Chinese Civilization: Japan, Korea, and Vietnam [w:] World Civilizations, eds. P.N. Stearns, M.B. Adas, S.B. Schwartz, M.J. Gilbert, $7^{\text {th }}$ ed., London 2014.

Szczepanski K., What is China's Mandate of Heaven?, 1.08.2019, https://www.thoughtco.com/themandate-of-heaven-195113 (dostęp: 12.02.2021).

The Yayoi Period (400 B.C. to 300 A.D.), www.japan-experience.com/to-know/the-history-of-japan/ yayoi-period (dostęp: 12.02.2021). 
Tokarczyk R., Wspótçesne kultury prawne, wyd. 9, Warszawa 2012.

Tubielewicz J., Historia Japonii, Wrocław 1984.

Ulak J.T., Hakubō period [w:] Encyclopaedia Britannica, www.britannica.com/art/Japanese-art/ Hakuho-period (dostęp: 12.02.2021).

Watanabe A. (渡辺晃宏), 平城京と木簡の世紀 [heijō kyō to mokkan no seiki], 日本の歴史 04 [Nippon no rekishi 04], Tokyo 2001.

Noda Y., Introduction to Japanese Law, transl. and ed. A.H. Angelo, Tokyo 1976.

Yoneda Y. (米田雄介), 郡司の研究 [gunji no kenkyū], (丵書·歴史学研究) [sōsho. rekishigaku kenkyū], Tokyo 19761976 .

Yoshimura M. (吉村昌輝), 鎌含本所法における博奕について [Kamakura Honjo hō ni okeru bakueki ni tsuite] [w: Y. Yasuyuki (吉田靖之), 法学政治学論究: 法律, 政治, 社会 [hōgaku seiji-gaku ronkyū: hōritsu seiji shakai], no. 43, Tokyo 1999.

Yoshimura T. (吉村武彦)，いわゆる「公地公民制」は存在したか, 古代史の新展開, [iwayuru 'kōchi kōmin-sei' wa sonzai shita ka, kodai-shi no shin tenkai], Tokyo 2005.

\section{SUMMARY}

\section{THE DEVELOPMENT OF JAPANESE LAW FROM THE ORIGINS OF JAPAN'S STATEHOOD UNTIL THE BEGINNING OF THE EDO PERIOD IN 1603. AN OUTLINE OF ISSUES}

The article outlines the most important aspects of the Japanese history and legal system until the beginning of Edo period in 1603. The work emphasizes and discusses the essential historical context and its effects on changing the Japanese legal system. This paper focuses on the specific conditions under which Japanese law was developed and on the influence of Chinese culture on the shaping of Japanese legal thought before the $17^{\text {th }}$ century. The work includes the distinction of the most important legal acts and implemented changes. It is an approach to better understand Japanese law in a historical context and the development of indigenous culture, customs, and beliefs. 